\title{
The Role of Organizational Culture and Transformational Leadership in Organizational Commitment
}

\author{
Pandapotan Sitompul ${ }^{1}$, Maria Francisca Lies Ambarwati ${ }^{2}$, Elkana Timotius ${ }^{3}$ \\ \{pandapotan.sitompul3064@gmail.com ${ }^{1}$, maria.ambarwati@starki.id ${ }^{2}$, mr.elkana@gmail.com ${ }^{3}$ \} \\ Sekolah Tinggi Ilmu Manajemen Saint Mary, Jl. K.H. Hasyim Ashari 54 Jakarta Pusat, Indonesia ${ }^{1}$, \\ ST IKS Tarakanita, Kompleks Billy \& Moon, Pondok Kelapa, Jakarta Timur 13450, Indonesia ${ }^{2}$, \\ Universitas Kristen Krida Wacana, Jl. Tanjung Duren Raya 4, Jakarta Barat $11470^{3}$
}

\begin{abstract}
The success of achieving business objectives determined by commitment in the organization when applying the strategies. The research aims to find the role of organizational culture and transformational leadership on organizational commitment. Low managerial level employees in Indonesia's leading private plantation company who have more than 5 years experiences and assigned in the plantation area were surveyed. It found that organizational culture and transformational leadership influence organizational commitment; both have a positive effect on organizational commitment. Organizations are strongly sugge sted to focus on organizational culture and transformational leadership for building organizational commitment.
\end{abstract}

Keywords: Organizational Commitment, Organizational Culture, Transformational Leadership

\section{Introduction}

All organizations need a commitment to carry out their activities in a long period. This commitment is reflected in the loyalty of employees towards the mission and goals of the organization, their responsibility on work, and their desire to remain part of the organization. Individual success commonly strengthened by the commit ment and can be measured on the job performance, attendance record, and the willingness to accept company policies.

The behavioural indicators of org anizational commitment are (1) willing to help others to complete the tasks of the organization, (2) prioritize activities to achieve organizational goals, (3) focus on organizational needs. Organizational commitment affects the loyalty of employees in the organization. Otherwise, employees who do not have organizational commitment will immediately resign because of unfavourable situations [1]. Commitment plays a role to improve performance because commitment encourages innovation [2]. Indeed, organizational commitment has developed into a multi-dimensional construction of performance through transformational leadership [3] [4].

Most research on organization commitment focused on the individual level but limited researches have been explored on the organizational level. This research examined the role of organizational culture and transformational leadership on organizational commitment and how both effects to strengthen it. The importance of this research emancipated from its aims which 
are to:

1. Review the antecedents of organizational commitment

2.Assess factors that influence the organizational commitment on the individual level

3. Explore the relationship of each factor to the organizational commitment

4.Examine the findings to theoretical underpinnings to analyse their roles.

The research is structured as: section one is the introduction. Section two presents the related theories from the latest literature as the theoretical study and theoretical framework. While section three explains the research method for hypotheses and data collection process. Section four explores findings to examine hypotheses. Conclusion, including limitations and suggestions for future researches, are presented in the last section.

\section{Literature review}

\subsection{Theoretical study}

\section{Organizational commitment}

Organizational commitment arises when employees have the same goals as the organization and loyal to the organization for achieving goals [5]. It becomes the individual pride and identity in the organization [6] and wants to always be in the organization [7]. Organizational commitment encourages employees to perform and have high morale.

Three types of commitments which are engaged employees and organizations: affective commit ment, normative commitment and continuous commitment [7]. Affective commitment is an emotional and identity employee in the organization. Normative commitment is convinced by responsibility as an employee. Continuous commitment comes from the employee's awareness that will suffer if leave the organization; the employee has high expectations on the organization and keeps to stay in the organization.

\section{Organizational culture}

Organizational culture is defined as a system of shared actions, values, and beliefs in an organization that shapes the behaviour of its members [8]. Organizational culture is shared social knowledge in an organization about rules, norms, and values that shape the attitudes and behaviour of its members [9]. Organizational culture is a set of shared values and beliefs according to corporate identity [10]. Organizational culture is a system of shared meanings owned by members that distinguish organizations fromother organizations [11]. Organizational culture is a set of values and assumptions shared within an organization [12].

Organizational culture refers to an environment and personality [13]. Organizational culture is a pattem of basic assumptions made, discovered, or developed by groups when adapting external and intemal problems to establis $h$ the proper way to realize, think, and feel the problem [14]. Organizational culture becomes a collection of traditions, values, policies, beliefs and attitudes that must be carried out and thought about by members of the organization [15]. Organizational culture is an employee's feelings and perceptions that create a sense and pattem of shared beliefs, values, and expectations [16]. Seven main characteristics in organizational 
culture: (1) innovation and risk-taking, (2) attention to detail, (3) results-oriented, (4) people orientation, (5) team orientation, (6) aggressiveness, and (7) stability [17].

\section{Transformational leadership}

The achievement of organizational goals depends on leadership style to influence, empower, and stimulate subordinates to work together achieving the organization's vision. Transformational leadership is can stimulate and inspires followers to achieve results because the leaders challenge themselves to innovate, solve problems, and develop their capacity [18].

Transformational leaders hip is the behaviour of a leader who encourages moral values to followers and generates their resources for the organization [19]. Trans formational leadership occurs when a leader can inspire subordinates to commit to the vision by acting as a model to develop potential and provide new perspectives [20]. Transformational leadership is a leader who changes an organization by creating, communicating, becoming a model of organizational vision and encouraging subordinates to achieve the vision of the organization [21]. Transformational leadership uses charisma to change and revitalize an organization by generating emotions and support followers independently [22].

\subsection{Theoretical framework}

The culture in each organization is different. A socialization process is sugges ted for new members to support them adapt and fosters confidence towards organizational commitment [23]. Hence; H1 - Organizational culture is positively related to organizational commitment. Besides, transformational leadership strongly positive effect on commitment [26] and strengthen organizational commitment when applied properly [27] [28] [29]. Hence; H2Transformational leadership is positively related to organizational commitment, and $\mathrm{H} 3-$ Organizational culture and transformational leadership are positively related to organizational commitment. Figure 1 draws the relationship of both organizational culture and transformational leadership on organizational commitment as the theoretical framework of this research to develophypotheses development.

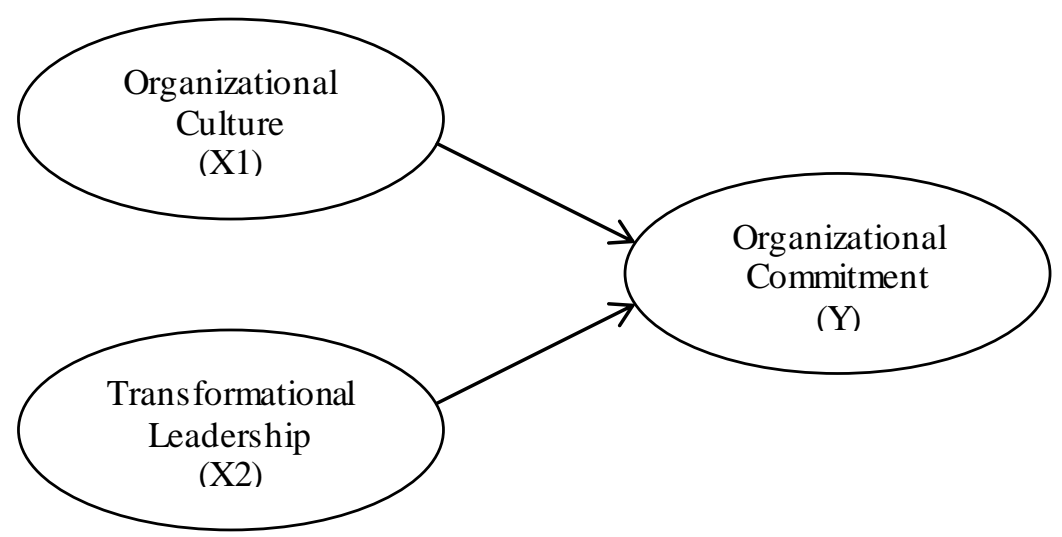

Fig. 1. The theoretical framework of the research. 


\section{Methods}

This research was conducted at PT Gunung Sejahtera Ibu Pertiwi, a leading private plantation company in Indonesia, in the third quarter of 2019. Preliminary research found weak organizational commitment in the company. By us ing quantitative analys is, 103 employees who were at a low managerial level with work experience of more than five years and assigned to the plantation area were surveyed. This draws inaccuracy 0.05 out of 138 populations using the Slovin formula.

\section{Results}

\subsection{Statistic des cription}

Organizational commit ment (Y) was examined by 30 valid questions and analyzed using multiple linear regression (Figure 2), obtained the mean value of 118.04 and the standard deviation of 8.865 .

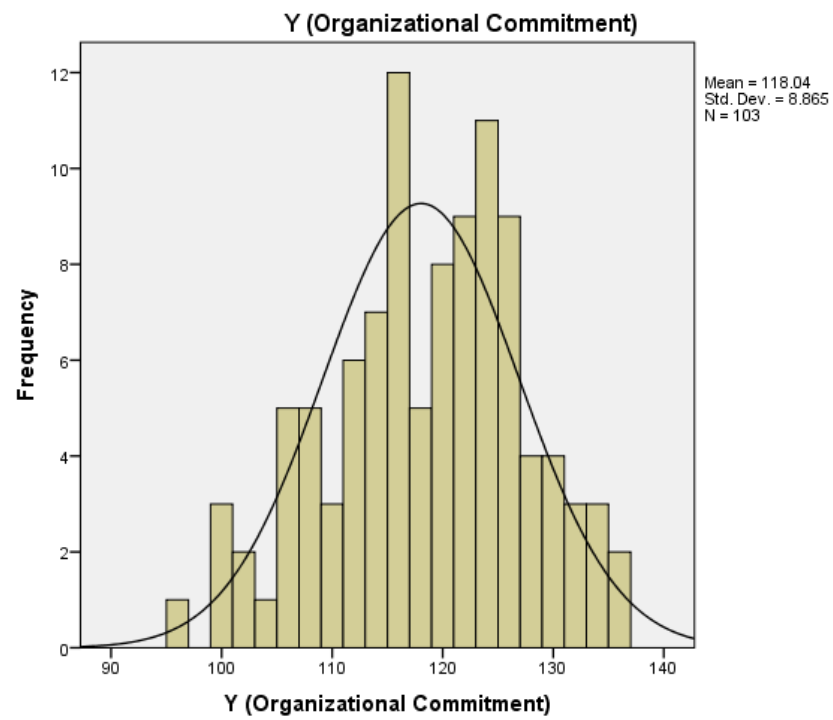

Fig. 2. Histogram and normal curve of organizational commitment variable.

Organizational culture (X1) was examined by 28 valid questions and analyzed using multiple linear regression (Figure 3), resulted in the mean value of 102.32 and the standard deviation of 11.540 . 


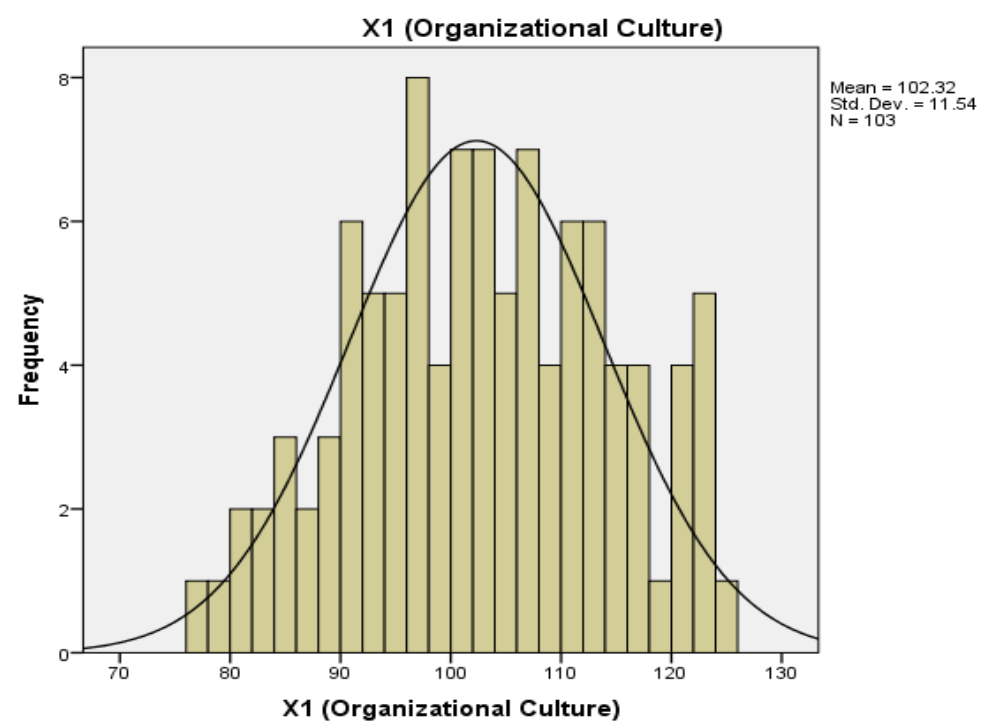

Fig. 3. Histogram and normal curve of organizational culture variable.

Transformational leadership (X2) was examined by 29 valid questions and analyzed using multiple linear regression (Figure 4), resulted in the mean value of 100.14 and the standard deviation of 14.071.

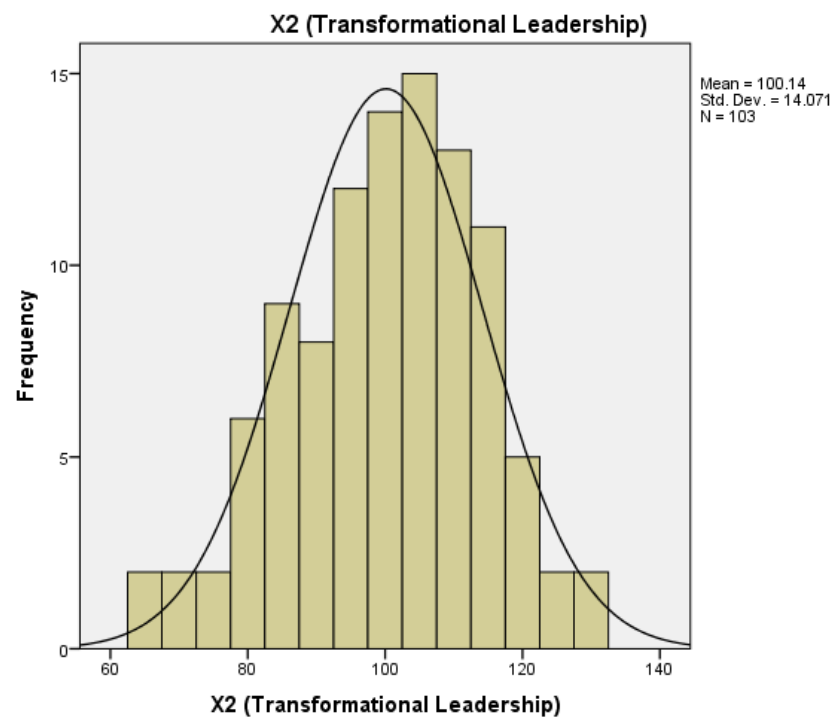

Fig. 4. Histogram and normal curve of transformational leadership variable. 


\subsection{Basic assumption test}

\section{Normality test}

The normality test of Kolmogorov-Smirnov was applied to find the significance value of organizational commitment $(\mathrm{Y})$, organizational culture $\left(\mathrm{X}_{1}\right)$ and transformational leadership $\left(\mathrm{X}_{2}\right)$ as 0.200 (Table 1). It means that the data were distributed normally.

Table 1. Normality test result.

Tests of Normality

\begin{tabular}{|c|c|c|c|c|c|c|}
\hline & \multicolumn{3}{|c|}{ Kolmogorov-Smirnov ${ }^{\mathrm{a}}$} & \multicolumn{3}{|c|}{ Shapiro-Wilk } \\
\hline & Statistic & $d f$ & Sig. & Statistic & $d f$ & Sig. \\
\hline $\begin{array}{l}Y \text { (Organizational } \\
\text { Commitment) }\end{array}$ & .071 & 103 & $.200^{\pi}$ & .984 & 103 & .232 \\
\hline $\begin{array}{l}\text { X1 (Organizational } \\
\text { Culture) }\end{array}$ & .048 & 103 & $.200^{*}$ & .983 & 103 & .213 \\
\hline $\begin{array}{l}\text { X2 (Transformational } \\
\text { Leadership) }\end{array}$ & .068 & 103 & $.200^{\pi}$ & .988 & 103 & .484 \\
\hline
\end{tabular}

*. This is a lower bound of the true significance.

a. Lilliefors Significance Correction

\section{Linearity test}

The linearity significance value of Y-X1 is 0.000 (Table 2), means organizational commitment (Y) had a linear relationship with organizational culture (X1).

Table 2. Linearity test of Y-X1 result.

ANOVA Table

\begin{tabular}{|c|c|c|c|c|c|c|c|}
\hline & & & $\begin{array}{l}\text { Sum of } \\
\text { Squares }\end{array}$ & df & Mean Square & $\mathrm{F}$ & Sig. \\
\hline \multirow{5}{*}{$\begin{array}{l}Y \text { Y (Organizational } \\
\text { Commitment) * }{ }^{*} 1 \\
\text { (Organizational Culture) }\end{array}$} & \multirow[t]{3}{*}{ Between Groups } & (Combined) & 3993.628 & 43 & 92.875 & 1.362 & .134 \\
\hline & & Linearity & 1763.657 & 1 & 1763.657 & 25.870 & .000 \\
\hline & & Deviation from Linearity & 2229.971 & 42 & 53.095 & .779 & .802 \\
\hline & \multicolumn{2}{|l|}{ Within Groups } & 4022.217 & 59 & 68.173 & & \\
\hline & \multicolumn{2}{|l|}{ Total } & 8015.845 & 102 & & & \\
\hline
\end{tabular}

Meanwhile, the linearity significance of Y-X2 is 0.000 (Table 3), means organizational commitment $(\mathrm{Y})$ had a linear relationship with transformational leadership (X2). 
Table 3. Linearity test of $\mathrm{Y}-\mathrm{X} 2$ result.

ANOVA Table

\begin{tabular}{|c|c|c|c|c|c|c|c|}
\hline & & & $\begin{array}{c}\text { Sum of } \\
\text { Squares }\end{array}$ & $d f$ & Mean Square & $\mathrm{F}$ & Sig. \\
\hline \multirow{5}{*}{$\begin{array}{l}\mathrm{Y} \text { (Organizational } \\
\text { Commitment) }{ }^{*} \mathrm{X} 2 \\
\text { (Transformational } \\
\text { Leadership) }\end{array}$} & \multirow[t]{3}{*}{ Between Groups } & (Combined) & 5547.428 & 49 & 113.213 & 2.431 & .001 \\
\hline & & Linearity & 988.759 & 1 & 988.759 & 21.230 & .000 \\
\hline & & Deviation from Linearity & 4558.669 & 48 & 94.972 & 2.039 & .006 \\
\hline & \multicolumn{2}{|l|}{ Within Groups } & 2468.417 & 53 & 46.574 & & \\
\hline & \multicolumn{2}{|l|}{ Total } & 8015.845 & 102 & & & \\
\hline
\end{tabular}

\section{Hypothesis test}

Each hypothes is was examined by multiple regressions to find the influence of each variable (Table 4).

Table 4. Multiple regression output of organizational culture (X1) and transformational leadership (X2) on organizational commitment (Y).

Coefficients $^{\mathrm{a}}$

\begin{tabular}{|c|c|c|c|c|c|c|}
\hline \multirow[b]{2}{*}{ Mode } & & \multicolumn{2}{|c|}{ Unstandardized Coefficients } & \multirow{2}{*}{$\begin{array}{c}\begin{array}{c}\text { Standardized } \\
\text { Coefficients }\end{array} \\
\text { Beta } \\
\end{array}$} & \multirow[b]{2}{*}{$t$} & \multirow[b]{2}{*}{ Sig. } \\
\hline & & $B$ & Std. Error & & & \\
\hline \multirow[t]{3}{*}{1} & (Constant) & 65.526 & 7.950 & & 8.242 & .000 \\
\hline & $\begin{array}{l}\text { X1 (Organizational } \\
\text { Culture) }\end{array}$ & .331 & .065 & .431 & 5.129 & .000 \\
\hline & $\begin{array}{l}\text { X2 (Transformational } \\
\text { Leadership) }\end{array}$ & .186 & .053 & .296 & 3.518 & .001 \\
\hline
\end{tabular}

a. Dependent Variable: $Y$ (Organizational Commitment)

The first hypothes is is organizational culture (X1) has a positive effect on organizational commitment $(\mathrm{Y})$. The analys is obtained the standardized coefficient of organizational culture (X1) on organizational commitment (Y) as 0.431 with a significance of 0.000 . It accepted the first hypothes is that organizational culture (X1) has a positive effect on organizational commitment (Y).

The second hypothes is is transformational leadership (X2) has a positive effect on organizational commitment (Y). The analys is obtained the standardized coefficient of transformational leadership (X2) on organizational commitment (Y) as 0.296 with a significance of 0.001 . It accepted the second hypothes is that trans formational leadership (X2) has a positive effect on organizational commitment $(\mathrm{Y})$.

The third hypothesis is organizational culture (X1) and trans formational leadership (X2) has a positive effect on organizational commitment (Y). The analysis obtained the sig value as 0.000 (Table 5). It accepted the third hypothesis that organizational culture (X1) and trans formational leadership (X2) has a positive effect on organizational commitment (Y). 
Table 5. ANOVA output of organizational culture (X1) and transformational leadership (X2) on organizational commitment (Y).

ANOVA $^{\text {a }}$

\begin{tabular}{|ll|c|r|r|r|c|}
\hline Model & & \multicolumn{1}{c|}{$\begin{array}{c}\text { Sum of } \\
\text { Squares }\end{array}$} & \multicolumn{1}{c|}{$\mathrm{df}$} & Mean Square & $\mathrm{F}$ & Sig. \\
\hline 1 & Regression & 2452.169 & 2 & 1226.085 & 22.037 & $.000^{\mathrm{b}}$ \\
& Residual & 5563.676 & 100 & 55.637 & & \\
& Total & 8015.845 & 102 & & & \\
\hline
\end{tabular}

a. Dependent Variable: $Y$ (Organizational Commitment)

b. Predictors: (Constant), X2 (Transformational Leadership), X1 (Organizational Culture)

\section{Discussion}

The examined hypothesis states that organizational culture influences as $43.1 \%$ to organizational commitment. This is consistent with the theory that organizational culture is a variable that causes changes in organizational commit ment [24] [25] [26]. This research proves that org anizational culture theoretically influences organizational commitment.

The effect of transformational leadership on organizational commitment is $29.6 \%$. This supports that transformational leadership theoretically has a strong positive effect on organizationalcommitment [26] [27] [28] [30].

The research found that organizational culture and transformational leadership simultaneously influence organizational commitment. Transformational leadership and organizational culture theoretically produce organizational commitment through employee performance and satisfaction [1].

\section{Conclusion}

According to statistical analys is, the research proves that organizational culture affects on organizational commitment, so does the transformational leadership. Both are also affecting organizational commitment.

The research has some limitations. There are only two variables to evaluate their roles in organizational commitment. To have more accurate findings, future researches can develop with other variables. Therefore, in the future research, data can be enlarged to some similar organizations.

\section{Acknowledgement}

The researchers would like to thank Herina as the Human Resources Development Manager at PT. Gunung Sejahtera Ibu Pertiwi who has given permission and assistance to conduct the research successfully. 


\section{References}

[1] Colquitt et al.: Organizational behavior: Improving performance and commitment in the Workplace. New York: McGraw-Hill (2009)

[2] Inanlou \& Ahn: The effect of organizational culture on employee commitment: A mediating role of human resource development in Korean firms. Journal of Applied Business. Vol. 33, No. 1 (2017)

[3] Porter, J. A.: The relationship between transformational leadership and organizational commitment in nonprofit long term care organizations: The direct care worker perspective. Journal of Interdisciplinary Leadership. Vol. 1, No. 2, pp. 68-85 (2015)

[4] Njoroge et al.: Transformational leadership style and organizational commitment: The moderating effect of employee participation. Strategic Journal Business Change Management. Vol. 2, No. 6, pp. 94-107 (2015)

[5] Robbins \& Coulter: Management. Prentice Hall (2008)

[6] Schermerhorn, S., Hurn, Osborn: Organizational behavior. New Jersey: John Wiley \& Sons (2010)

[7] Robbins \& Judge: Organizational behavior. New Jersey: Pearson Prentice Hall (2007)

[8] Schermerhorn, B. \& Hurn: Organizational behavior. New Jersey: John Wiley \& Sons, Inc. (2011)

[9] Colquitt, W.: Organizational behavior: Improving performance and commitment in the workplace. New York: McGraw-Hill (2011)

[10] Kreitner \& Kinicki: Organizational behavior: Key concepts, skills, and best practices. New York: McGraw-Hill (2010)

[11] Robbins, T. A. \& Judge, S. P.: Organizational behavior, 16th ed. England: Pearson (2015)

[12] McShane \& Glinow: Organizational behavior. New York: McGraw-Hill (2010)

[13] Sherriton \& Stern: Corporate culture. New York: Corporate Management Developers (1997)

[14] Luthans, F.: Organizational behavior. New York: McGraw-Hill (2005)

[15] Mullins, L. J.: Management and organizational behavior. New Jersey: Prentice Hall (2005)

[16] Gibson et al.: Organizational behavior: Structure and processes. Singapore: McGraw-Hill (2009)

[17] Robbins \& Judge: Organizational behavior. New Jersey: Englewood Cliffs: Pearson Prentice-Hall (2011)

[18] Bass \& Riggio: Transformational leadership. New Jersey: Lawrence Erlbaum Associates Publishers (2006)

[19] Yukl, G.: Leadership in organizations. New York: Pearson Education International (2006)

[20] Colquitt, W.: Organizational improving performance and commitment in the workplace. New York: McGraw-Hill Irwin (2009)

[21] McShane \& Glinow: Organizational behavior. New York: McGraw-Hill Irwin (2009)

[22] Greenberg \& Baron: Behavior in organizations. New Jersey: Pearson Education (2008)

[23] Robbins, S. P.: Organizational behavior. New Jersey: Englewood Cliffs: Pearson Prentice-Hall (2011)

[24] Momeni, S. \& Marjani: The relationship between organizational culture and organizational commitment in staff department of general prosecut ors of Tehran. International Journal of Business and Social Science, Vol. 3, No. 13, pp. 217-221 (2012)

[25] Yavuz, M.: The effects of teachers' perception of organizational justice and culture on organizational commitment. African Journal of Business Management, Vol. 4, No. 5, pp. 695-701 (2010)

[26] Robbins, S. P.: Organizational behaviour, 8th ed. USA: Prentice Hall (2000)

[27] Colquitt et al.: Organizational performance and commitment in the workplace. New York: McGraw-Hill (2009)

[28] Ismail, M. \& Sulaiman, M.: An empirical study of the relationship between transformational leadership, empowerment and organizational commitment. Business Economic Resources Journal, 
Vol. 2, No. 1,pp. 89-107 (2011)

[29] Bushra, N. \& Usman: Effect of transformational leadership on employees' job satisfaction and organizational commitment in banking sector of Lahore (Pakistan). International Journal of Business and Social Science, Vol. 2, No. 18, pp. 261-267 (2011)

[30] Navalino, H. \& Astuti, N.: The effect of downsizing on transformational leadership, organizational climate, organizational commitment and employee performance. IOSR Journal of Business Management, Vol. 16, No. 9, pp. 32-39 (2014) 